\title{
A Spatial Valence Model of Political Participation in China
}

\author{
Jason $\mathrm{Y} . \mathrm{Wu}^{*}$ \\ Indiana University \\ October 25, 2018 \\ Forthcoming, Journal of Theoretical Politics
}

\begin{abstract}
In spatial models of political competition in democracies, citizens vote for the party or candidate that is the closest to their own ideological position, while in valence models, voters decide on the basis of non-policy factors, such as competence. What remains unclear, however, is whether citizens in authoritarian regimes use spatial or valence considerations to guide their decisions to participate in politics. This study uses data from the 2015 Chinese Urban Governance Survey to measure the ideology of Chinese citizens, and estimates an empirical stochastic model to explore how Chinese citizens use ideological distance and valence to determine how they want to participate in politics. The results show that valence issues, such as perceived government competence, play a larger role in political participation than ideology.
\end{abstract}

I would like to thank James Adams, Claire Adida, Dan Chen, Bruce Dickson, Greg Distelhorst, Lei Guang, Steph Haggard, Seth Hill, Indriði Indriðason, Anna-Sophie Kurella, David Lake, Tianguang Meng, Molly Roberts, Sebastian Saiegh, Victor Shih, Susan Shirk, Michael Thies, Yiqing Xu, and Ning Zhang for their suggestions. Panel participants at APSA 2016, ACPS 2016, SCPI XII, and the Fudan-UC Young Scholars Conference also provided helpful feedback. This research was supported in part by the Smith Richardson Foundation, the Chiang Ching-Kuo Foundation, the 21st Century China Center, and the Carnegie Corporation of New York.

*jywu@indiana.edu. 


\section{Introduction}

How do people make political choices under authoritarian rule? Spatial theories of political behavior in democracies model voting using the ideological distance between individuals and political parties, while valence theories argue that non-policy evaluations of a political actor are also important. Whether citizens in autocracies primarily participate in politics because of ideological or valence motivations is an open question. In this paper I use a survey of Chinese citizens and an empirical stochastic model which incorporates both spatial distance and valence to venture an answer to this question. I find that while the spatial model does explain a significant part of the decision to consider protesting or the decision to join the Communist party, valence, and in particular evaluations of the government's competence, is a more important factor for explaining political participation in China.

The logic of the spatial model also predicts that political actors should locate themselves at a particular point in the ideological space to maximize their popular support. In the classic spatial model, which considers ideology along one dimension and models individual choice in a deterministic fashion, that point is the median voter (Downs 1957; Riker and Ordeshook 1973). In stochastic spatial models, parties are expected to converge on the electoral mean (McKelvey and Patty 2006). These results are at odds with cases such as the US, where political parties fail to converge on the median voter. To reconcile this divide between theory and outcomes, Schofield (2007) incorporates asymmetries in valence into the model. In the Schofield model, political parties do not necessarily converge on the electoral mean in equilibrium. Lower-valence political actors may be forced to move to the fringe of the ideological space to maximize their support.

Although the spatial model was designed to explain electoral politics, a similar spatial logic guides political contestation in authoritarian regimes. High valence political actors, such as the government, attempt to occupy the center of the ideological space and paint the potential opposition as the ideological fringe (Schofield and Levinson 2008). In my analysis, I find that ideological distances between Communist party 
members and members of the potential opposition are relatively small, and that both groups locate themselves close to the center of the ideological space. This result suggests that citizens choose between the Communist party and the potential opposition on the basis of valence issues, rather than ideological ones.

In the next section of this paper, I review previous research on the spatial model and generate our theoretical expectations for how ideology and valence operate in China. Then, after sketching Schofield's spatial valence model, I explain how I constructed my measures of ideology, estimate the model, and present the empirical results. The conclusion explores some of the implications of the findings for political contestation in China in the future.

\section{Spatial and Valence Explanations of Political Be-} havior

In the classic spatial model popularized by Hotelling (1929) and Downs (1957), political parties are motivated by holding office and choose a policy position in the ideological space to maximize their share of the vote. Citizens vote for the party that has the policy position that is closest to their own views. Under this framework, political parties converge on the median voter, which leaves voters indifferent between their electoral choices.

One of the early objections to this line of reasoning was that not all issues lent themselves to variation along an ideological space. While public opinion is divided in its support for some policies, such as the proper level of state involvement in the economy, for certain valence issues, such as the need for honest leaders, or the need for competent administration, there is broad consensus among the public. When politicians campaign on valence issues, instead of taking specific policy positions, they attempt to associate themselves with some sort of positive symbol or goal, such as honesty or competence (Stokes 1963, 1992). If they succeed in drawing some type of valence 
distinction between themselves and their opponents, then they may not need to converge to the same ideological position.

In recent years, scholars of mass-elite linkages have sought to formally combine spatial models of political competition with valence issues (Ansolabehere and Snyder 2000; Groseclose 2001). Empirical work in this literature has modeled vote choice probabilistically, using a mixed logit statistical model (Adams et al. 2005; Adams and Merrill 1999; Micozzi and Saiegh 2015; Schofield and Sened 2005). By combining spatial and valence considerations, these models can help explain why parties fail to converge on the mean voter in some cases. In majoritarian or winner-take-all electoral systems, these models find that centripetal electoral forces tend to encourage political parties to converge on the center (Schofield et al. 2011a; Schofield et al. 2011b), but in proportional electoral systems, these models expect parties to diverge in equilibrium (Schofield and Sened 2005; Schofield et al. 2011c; Kurella and Pappi 2015).

Studies of hybrid regimes or electoral autocracies in this framework find that valence is an especially important factor in political behavior. In Russia, for instance, while ideological distance was a significant factor in the 2007 Duma elections, a voter's opinion of Vladimir Putin was the most important factor for vote choice (Schofield and Zakharov 2009). Similarly, in Singapore, ideological alignments are a lesser factor than valence issues, such as perceptions of party credibility, in voting decisions (Oliver and Ostwald 2018). Valence differences also explain why political parties in electoral autocracies fail to converge on the mean voter. One common result is that lower-valence opposition parties are forced to the fringe of the ideological space, while the highervalence ruling party occupies the center of the distribution (Schofield et al. 2011c; Schofield et al. 2012). Because the government maintains control over the media in these states, opposition parties are often forced to use protests to express their discontent with government policy. This tends to make it difficult for the opposition to raise its valence in the eyes of the general population.

Since the empirical study of ideology under authoritarian rule is still in its early 
stages, ${ }^{1}$ what remains unclear is whether a spatial logic guides the political behavior of citizens in personalist, military, or single-party authoritarian regimes. If citizens decide to support the regime or rebel because of the spatial distance between them and the government, then autocrats may feel the constraints of the public's policy preferences even in the absence of free and fair elections. However, if valence issues predominate, then an autocrat may be able to select an ideal point that is far from the average citizen and stay in power, so long as the regime maintains a valence advantage over the potential opposition.

Schofield and Levinson (2008) argue that political contestation in authoritarian regimes can be understood according to the logic of the spatial valence model. The autocrat generally attempts to capitalize on his high valence by occupying the center of the ideological space. This way, he has the option of co-opting potential opposition by offering policy compromises. Dictators often lose power when they lose their valence advantage or allow the potential opposition to occupy the center of the ideological space.

\section{Theoretical Expectations}

The leaders of the Chinese Communist Party have often argued that incorrect ideological positioning undermines its control over society. One theme of official doctrine is the need to avoid veering too far to the "Left" or the "Right."

In a 1955 speech at a national Communist Party conference, Mao explained that "to move far ahead of the times, to outpace current developments, to be rash in action and in matters of principle and policy and to hit out indiscriminately in struggles and controversies - these are "Left" deviations and are no good. To fall behind the times, to fail to keep pace with current developments and to be lacking in militancy - these are Right deviations and are no good either" (Mao 1977, 167).

As Mao grew frustrated with the bureaucracy's resistance to his efforts to transform Chinese society, more and more officials began to find themselves accused of ideological deviancy. During the purges of the Anti-Rightist Movement and the Cultural Revolu-

\footnotetext{
${ }^{1}$ See Lu et al. (2016); Pan and Xu (2018); Wu and Meng (2016) for new work in this area.
} 
tion, the range of acceptable ideological views converged to Mao's purported positions (MacFarquhar and Schoenhals 2006; Nathan and Shi 1996).

After Mao's death, the party concluded that the Cultural Revolution had been a grave "Left" error which was both the product of Mao's mistakes and an aberration inconsistent with Mao Zedong Thought (CCP Central Committee 1981). ${ }^{2}$ After ascending to power, Deng Xiaoping cautioned that the party needed to return to the center. In his speech "Uphold the Four Cardinal Principles," he argued "both the ultra-Left and Right currents of thought run counter to Marxism-Leninism and Mao Zedong Thought and obstruct our advance towards modernization" (Deng 1984, 173).

This rhetorical tradition leads us to a theoretical expectation for the Communist Party, which is that it will attempt to locate itself in the center of the ideological spectrum. If this is the case, then we might also expect that the individuals who choose to join the party are relatively centrist in their ideological views, and that they become party members for valence reasons. This expectation is in keeping with the party's strategy of preferentially enrolling the elite segments of Chinese society (Dickson and Rublee 2000), and with the fact that many party members join the party to advance their career prospects and enjoy access to particularistic benefits (Dickson 2014).

The motivations of the potential opposition are necessarily more opaque. Participation in collective action may be driven by ideological factors, such as opposition to the political system, or by valence issues, such as dissatisfaction with corrupt or inept administration.

Citizens who contemplate joining a protest must moreover grapple with the Communist party's efforts to design and restrict the scope of contention. In recent years, the party has established a pattern of compensating some of the protesters who limit their demands to the resolution of localized grievances, while cracking down on those who put forward a broader agenda. By organizing its repressive strategies in this way, the

\footnotetext{
${ }^{2}$ In this account, the political mistakes of other CCP leaders were also essentially ideological ones. Chen Duxiu's "Right capitulationism" had led to the CCP's misfortune in the 1927 Shanghai massacre, while Wang Ming's "Left" adventurism produced defeat to the KMT during the civil war. Hua Guofeng's "Two Whatevers" policy after Mao's death was also deemed a Leftist error.
} 
CCP has preserved the informational value of protests to party leaders while limiting their ability to transfer information between members of the general public. Striking this balance has allowed the party to contain the threat that protesters pose to the regime (Lorentzen 2013, 2017).

The few activists who do organize on behalf of an explicit ideological agenda are swiftly punished by the party. Dissidents such as the founders of the China Democratic Party and the leaders of the Charter 08 movement are either arrested or sent into exile, where they often fall out amongst themselves (Potter 2011). Censors prevent the policy demands of these activists from being discussed, while party propagandists accuse them of carrying water for hostile foreign forces (Wright 2002). The CCP's ability to preclude the formation of a viable alternative to its rule ensures that the potential opposition remains leaderless, fragmented, and low in valence.

The party's efforts to manipulate the incentives of discontented citizens present them with an uncomfortable choice. Citizens who remain determined to take action often present themselves as wronged loyalists engaging in "rightful resistance" (O'Brien 1996; O'Brien and Li 2006), confine themselves to narrower issues, such as land expropriation or pollution (Deng and Yang 2013; Guo 2001), or disguise their mobilization strategy by protesting alone (Fu 2017). The adjustments made by these protesters generally blunt the ideological edge to their demands and emphasize their dissatisfaction with the valence of low-level officials.

As a result, we might anticipate that most of the citizens who are willing to take part in collective action are making a decision that is driven by the valence of the government, and in particular by perceptions of government competence. They may consider protesting even if their ideological preferences are largely the same as the policy positions put forward by the party.

\section{An Empirical Stochastic Model}

In this study I use Schofield's stochastic valence model to assess the motivations that drive political participation in China. Formally, the model $M(\lambda, \beta)$ has individual 
utility which is determined by the expression

$$
u_{i j}\left(x_{i}, z_{j}\right)=\lambda_{j}-\sum_{k=1}^{\omega} \beta_{k}\left\|x_{i k}-z_{j k}\right\|^{2}+\epsilon_{i j}
$$

Here $\lambda_{j}$ is the exogenous valence of party $j$, and $\beta_{k}$ is a vector of positive ideological distances with length $\omega$, where $\omega$ is the number of dimensions in the ideological space. $x_{i k}$ is individual $i$ 's ideal point for the ideology dimension $k, z_{j k}$ is group $j$ 's ideological position on dimension $k$, and $\left\|x_{i k}-z_{j k}\right\|$ is the Euclidean distance between the respondent $x_{i k}$ and the group $z_{j k}$ on dimension $k . \epsilon_{i j}$ is the error term, which is assumed to follow the Type I extreme value or Gumbel distribution. This allows us to estimate the model in a multinomial logit (MNL) framework.

$M(\lambda, \beta)$ is a pure spatial model which only incorporates terms for spatial distance and valence. It is also possible to specify a joint model $M(\lambda, \theta, \alpha, \beta)$ if we model individual decisions with additional terms for socio-demographic variables and attitudes towards the government. If we model individuals this way, then utility for individual $i$ is governed by the equation

$$
u_{i j}\left(x_{i}, z_{j}\right)=\lambda_{j}+\left(\theta_{j} \cdot \nu_{i}\right)+\left(\alpha_{j} \cdot \tau_{i}\right)-\sum_{k=1}^{\omega} \beta_{k}\left\|x_{i k}-z_{j k}\right\|^{2}+\epsilon_{i j} .
$$

Here, $\theta_{j}$ is a vector that contains the effect of each sociodemographic variable (age, education, gender, and family income) on the choice to join group $j$, while $\nu_{i}$ is the vector of sociodemographic characteristics for individual $i$. The $\left(\theta_{j} \cdot \nu_{i}\right)$ terms are scalar products which we call the sociodemographic valences for group $j$.

$\alpha_{j}$ is a vector that contains the effect of an attitudinal variable (the perception of government competence) on the choice of group $j$, while $\tau_{i}$ is individual $i$ 's score on the competence measure. We call the scalar product $\left(\alpha_{j} \cdot \tau_{i}\right)$ the institutional valence for our model.

In traditional conceptions of the spatial model, political parties choose their ideological position to maximize their vote share. However in China, the regime does not allow political groups to maximize their support by publicizing an ideological program. 
As a result the ideology of a group is defined by the individual decisions made by its supporters. The ideology of each group for a given dimension $k$ is defined to be the mean ideology of the group members on that dimension. If we suppose that each individual $i$ chooses group $d_{i}$, and $N_{j}$ is equal to the number of individuals who chose group $j$, then

$$
z_{j k}=\frac{1}{N_{j}} \sum_{i \mid d_{i}=j} x_{i k}
$$

For both of our models, once we specify each group's ideological position with $\boldsymbol{z}$, the probability that individual $i$ chooses group $j$ is

$$
\rho_{i j}(z)=\operatorname{Pr}\left[\left[u_{i j}\left(x_{i}, z_{j}\right)>u_{i l}\left(x_{i}, z_{l}\right)\right] \text {, for all } l \neq j\right]
$$

In other words, an individual chooses to join one group to maximize her own payoff. This payoff is based on the distance between her own ideology and the ideal point of each of the groups, which we have defined to be the mean of all of the group members' ideal points. In the pure spatial model, this payoff is simply a function of the valence of each group and ideological distance, while in the joint model, this payoff is also shaped by an individual's sociodemographic characteristics and her perceptions of government competence.

\section{Empirical Analysis}

\section{Data and Measurement}

The data for this study come from the Chinese Urban Governance Survey (CUGS), which was administered in the summer of 2015 in 50 cities from 24 different provinces. This survey used GPS-assisted area sampling (Landry and Shen 2005) to generate a nationally representative urban sample of 3513 respondents. Respondents answered

a series of questions about political issues and the state's capabilities in a variety of areas, ranging from its ability to maintain social stability to its ability to provide 
social welfare. Table 1 reports the essential descriptive statistics, as well as an index for perceived government competence, which is calculated as the mean of the seven measures of government capabilities.

Table 1: Summary Statistics

\begin{tabular}{lccccc}
\hline \hline Statistic & $\mathrm{N}$ & Mean & St. Dev. & Min & Max \\
\hline Ideology (Left-Right) & 3,513 & 0.00 & 1.00 & -3.81 & 4.03 \\
Ideology (Authoritarian-Democratic) & 3,513 & 0.00 & 1.00 & -4.06 & 4.09 \\
CCP Member & 3,494 & 0.12 & 0.32 & 0 & 1 \\
Age & 3,513 & 43.20 & 15.04 & 18 & 70 \\
Education & 3,243 & 10.59 & 4.22 & 0 & 25 \\
Gender & 3,513 & 0.50 & 0.50 & 0 & 1 \\
Family Income & 1,112 & 72,848 & 78,025 & 2,500 & 800,000 \\
Willingness to Protest & 2,343 & 0.11 & 0.31 & 0 & 1 \\
Propaganda Capacity & 3,132 & 2.84 & 0.70 & 1 & 4 \\
Stability Capacity & 3,227 & 2.96 & 0.67 & 1 & 4 \\
Price Control Capacity & 3,034 & 2.81 & 0.73 & 1 & 4 \\
Tax Collection Capacity & 2,939 & 3.07 & 0.76 & 1 & 4 \\
Representation Capacity & 3,075 & 2.39 & 0.79 & 1 & 4 \\
Social Welfare Capacity & 3,138 & 2.37 & 0.77 & 1 & 4 \\
Control Cadres Capacity & 3,064 & 2.37 & 0.83 & 1 & 4 \\
Competence & 2,662 & 2.70 & 0.53 & 1 & 4 \\
\hline
\end{tabular}

Each respondent's ideological position was estimated using Bayesian item response theory (IRT) and a set of twelve ideology questions, which were selected to cover the most salient set of political, economic, and cultural issues in China. I used an ordinal model to take advantage of the full variation in the responses, which were on a four point scale (Quinn 2004).

A two-dimensional model best fits the ideology data from the survey. The first dimension, which I call Left-Right, captures a divide between pro-market and antimarket sentiments. For the Left-Right dimension, the most discriminating questions ask respondents whether they believe private ownership of property disadvantages working class people, whether privatization of state-owned enterprises should be outlawed, and whether state-owned enterprises should control the key sectors of the economy. ${ }^{3}$ Respondents who agreed with these statements received negative scores on the first

\footnotetext{
${ }^{3}$ Note that this is a narrower definition than the one used by Mao and other leaders of the CCP, which concerns the pace of societal change. For the purposes of this paper, the Left-Right axis captures a policy debate over the role of the state in the economy.
} 
dimension, which would put them on the left, while those who generally disagreed had positive scores, which are associated with the right.

The second dimension of ideology is associated with political and cultural divisions. The items that load most heavily on this dimension include questions about whether Western multiparty democracy is suitable for China, whether freedom of speech will lead to chaos, and whether Confucianism is suitable for modern Chinese society. Individuals who tended to agree with these statements received a negative score on the second dimension, which put them closer to the more authoritarian end of the spectrum; individuals who supported multiparty democracy and freedom of speech received positive scores on the second dimension.

Table 2 presents the difficulty and discrimination parameters for each ideology question. In general, the questions that load most heavily on a given dimension have discrimination parameters with high absolute values.

To estimate the spatial model, respondents were divided into four mutually exclusive groups based on whether they were members of the Communist Party and on whether they would be willing to consider protesting in the future. All respondents who were members of the party are coded as CCP Members, regardless of whether they said they would consider protesting. For the respondents who were not party members, those who said they would never protest were coded as Bystanders, those who were unsure as Undecideds, and those who would consider protesting in the future as Potential Protesters. $^{4,5}$ A total of 19 respondents did not answer the survey question about membership in the Communist Party and were dropped from the analysis, leaving us with a total of 3494 observations.

\footnotetext{
${ }^{4}$ These groups are analytic constructions and with the exception of the CCP Members, they are unable to coordinate on an ideological message. They also are not vote-maximizing entities. However, the logic of the spatial valence model still applies, insofar as individuals choose how they participate in politics (either by joining the party or contemplating protest) based at least in part on the ideological distance between them and other people engaging in the same activities.

${ }^{5}$ In the appendix I present additional results which are based on a different way of constructing groups. Following Alvarez et al. (2017), I use latent class analysis to divide the survey respondents into Outsiders, Agitators, Activists, and Conventionals based on their patterns of conventional and unconventional political participation. The results of this analysis are broadly consistent with the findings of the main text. Ideological distance on the second Authoritarian-Democratic dimension remains an important determinant of group choice, but the impact of perceived government competence is attenuated.
} 
Table 2: Difficulty and Discrimination Parameters

\begin{tabular}{|c|c|c|c|}
\hline & $\begin{array}{l}\text { Difficulty } \\
\text { Parameter }\end{array}$ & $\begin{array}{c}\text { Left-Right } \\
\text { Discrimination } \\
\text { Parameter }\end{array}$ & $\begin{array}{c}\text { Auth.-Dem. } \\
\text { Discrimination } \\
\text { Parameter }\end{array}$ \\
\hline \multicolumn{4}{|c|}{$\begin{array}{l}\text { Private ownership of property disadvantages working } \\
\text { class people }\end{array}$} \\
\hline 发展私有制经济会导致劳动人民沦为弱势群体 & 2.37 & -1.09 & 0.20 \\
\hline \multicolumn{4}{|c|}{$\begin{array}{l}\text { Privatizing the assets of state-owned enterprises should } \\
\text { not be allowed }\end{array}$} \\
\hline 不能允许民间资本兼并国有企业 & 1.75 & -0.80 & 0.17 \\
\hline \multicolumn{4}{|c|}{$\begin{array}{l}\text { Attempting to control real estate prices will undermine } \\
\text { economic development }\end{array}$} \\
\hline \multicolumn{4}{|l|}{$\begin{array}{l}\text { Sectors important to people's livelihoods must be } \\
\text { controlled by state-owned enterprises }\end{array}$} \\
\hline 关系到国计民生的领域, 必须全部由国有企业掌控 & 1.51 & -0.67 & 0.00 \\
\hline $\begin{array}{l}\text { Marketization exacerbates economic inequality } \\
\text { 市场化必然加剧贫富两极分化 }\end{array}$ & \multicolumn{2}{|c|}{ Marketization exacerbates economic inequality } & -0.01 \\
\hline \multicolumn{4}{|c|}{$\begin{array}{l}\text { Western Multiparty systems are unsuitable for China } \\
\text { in its current state }\end{array}$} \\
\hline 西方的多党制不适合中国国情 & 2.78 & -0.60 & -1.04 \\
\hline \multicolumn{4}{|l|}{$\begin{array}{l}\text { Media should be allowed to represent the voice of } \\
\text { specific social strata or interest groups }\end{array}$} \\
\hline 应当允许媒体代表特定阶层或利益集团发言 & 1.55 & -0.53 & -0.16 \\
\hline \multicolumn{4}{|l|}{$\begin{array}{l}\text { Indiscriminately imitating western-style freedom of } \\
\text { speech will lead to social disorder }\end{array}$} \\
\hline 照搬西方式的言论自由, 社会就乱了 & 2.34 & -0.50 & -0.76 \\
\hline \multicolumn{4}{|l|}{ The modern Chinese society needs Confucianism } \\
\hline 现代中国社会需要儒家思想 & 2.48 & -0.46 & -0.71 \\
\hline \multicolumn{4}{|l|}{ The minimum wage should be set by the state } \\
\hline 最低工资应由国家规定 & 2.19 & -0.44 & -0.40 \\
\hline \multicolumn{4}{|c|}{$\begin{array}{l}\text { China's current political system is the one that is best } \\
\text { suited for China's circumstances }\end{array}$} \\
\hline \multicolumn{4}{|l|}{ Individuals should be able to own land } \\
\hline 个人应当可以拥有土地 & 1.88 & -0.16 & -0.14 \\
\hline
\end{tabular}


Table 3: Group Proportions

\begin{tabular}{lcccc}
\hline \hline Group & Respondents & Percent of Sample & $\begin{array}{c}\text { Mean Left-Right } \\
\text { Ideology }\end{array}$ & $\begin{array}{c}\text { Mean Authoritarian- } \\
\text { Democratic Ideology }\end{array}$ \\
\hline Bystanders & 1821 & $52.1 \%$ & -0.046 & -0.040 \\
Undecideds & 1049 & $30.0 \%$ & 0.047 & 0.094 \\
Potential Protesters & 215 & $6.2 \%$ & 0.085 & 0.288 \\
CCP Members & 409 & $11.7 \%$ & 0.022 & -0.205 \\
\hline
\end{tabular}

Following previous research using the empirical stochastic model, the ideal point of each group is taken as the mean of the ideal points of the members of that group. Table 3 gives the proportion of our sample which fell into each group, as well as the mean ideal points for each group on both the Left-Right and the Authoritarian-Democratic dimensions of ideology. The left panel of figure 1 presents the distribution of ideology estimates for the survey as a whole, while the right panel shows a close-up of the center of our distribution. 
Figure 1: The Ideological Distribution of Protesters and Party Members in China

\section{Ideological Spectrum}

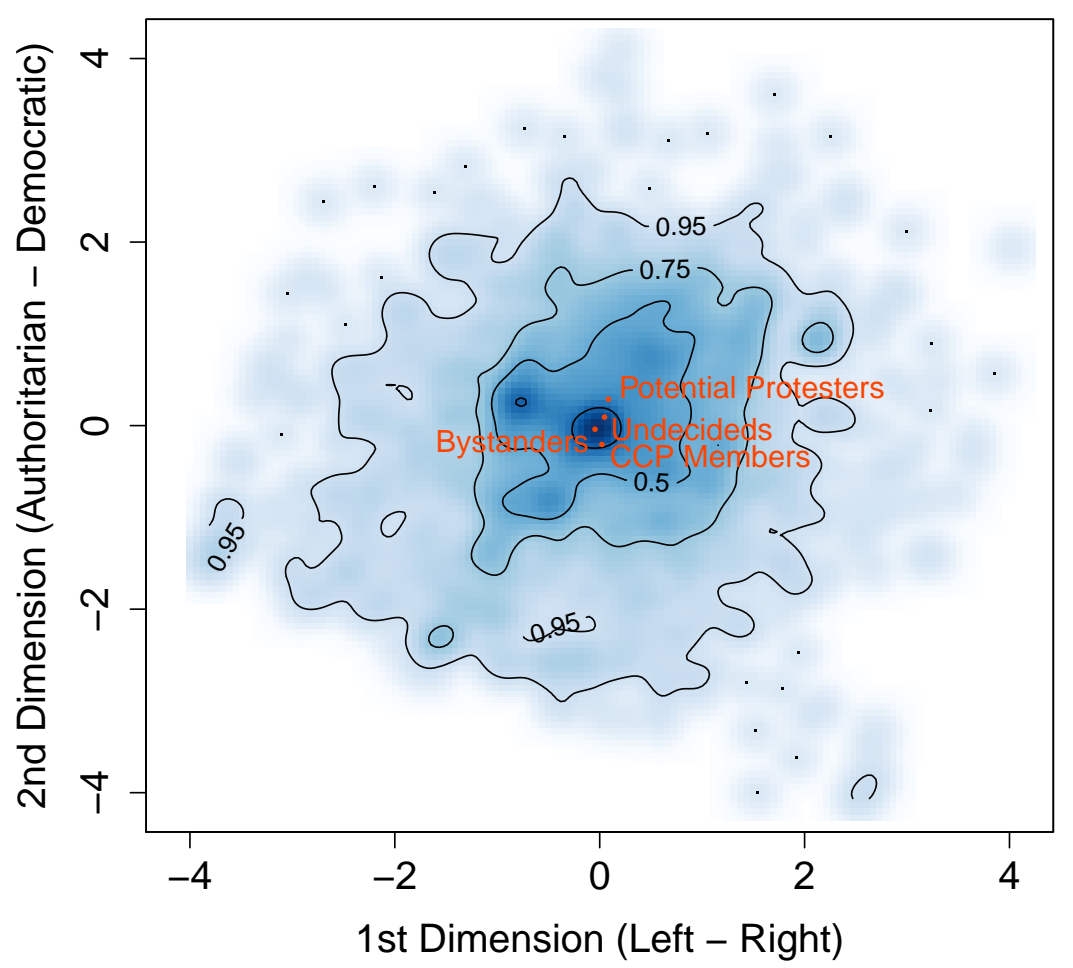

(a) The overall distribution of ideology in the sample

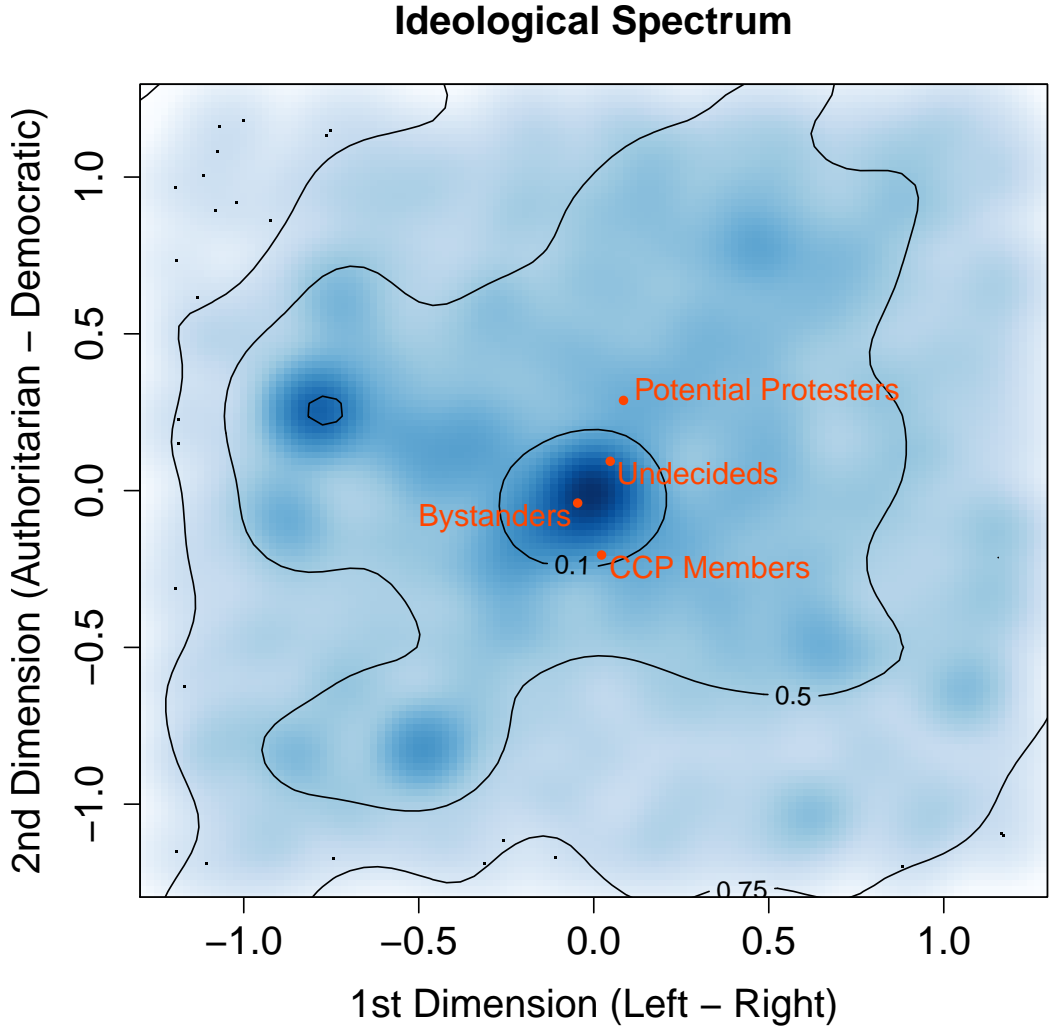

(b) A close-up view of the center of the ideology distribution 


\section{Results}

The results of our mixed logit model show that while both valence and ideological distance shape political participation decisions in China, valence is the more powerful factor. Institutional valence, or the perception of government competence, is the key factor that encourages individuals to consider protesting in the future, while sociodemographic valences, such as education, age, and income, are key factors that shape the decision to join the Communist Party.

Table 4 presents the results from the pure spatial model, $M(\lambda, \beta)$. In this model, the spatial coefficients for both the left-right and authoritarian-democratic dimensions of ideology are significant. The valence terms are calculated with respect to the Bystanders, who are the highest valence group.

Table 4: Pure Spatial Model Results (base Bystanders)

\begin{tabular}{lc}
\hline \hline Variable & Coefficient (Std. err.) \\
\hline Spatial distance & \\
Left-Right Ideology $\left(\beta_{1}\right)$ & $0.379^{* *}(0.181)$ \\
Auth.-Dem. Ideology $\left(\beta_{2}\right)$ & $0.492^{* * *}(0.075)$ \\
& \\
Valence terms & $-2.137^{* * *}(0.073)$ \\
Potential Protesters $\left(\lambda_{\text {Protesters }}\right)$ & $-0.552^{* * *}(0.039)$ \\
Undecideds $\left(\lambda_{\text {Undecideds }}\right)$ & $-1.492^{* * *}(0.055)$ \\
CCP Members $\left(\lambda_{C C P}\right)$ & 3,494 \\
\hline Observations & $-3,899.469$ \\
Log Likelihood & ${ }^{*} \mathrm{p}<0.1 ;{ }^{* *} \mathrm{p}<0.05 ;{ }^{* * *} \mathrm{p}<0.01$ \\
\hline \hline Note:
\end{tabular}

I also estimate a joint model, $M(\lambda, \theta, \alpha, \beta)$, which includes sociodemographic terms and a measure of institutional valence, the perceived competence of the government. To alleviate missing data concerns, I conducted the multinomial logit analysis after multiple imputation. Table 5 presents the results of the joint model after imputation, while Table A.1 in the appendix presents the results of the model if listwise deletion is used to deal with missing observations. 
The results show that spatial distances on the authoritarian-democratic dimension of ideology explain how individuals choose to protest or join the party in China. Individuals do not, however, choose how they participate based on the left-right dimension of ideology, which concerns the proper role of the state in the economy. This result is robust to imputation and runs counter to our intuitions formed from similar analyses of democracies, where economic ideology is typically a strong factor that shapes vote choice (Schofield et al. 2011b; Schofield et al. 2011c).

Table 5: Joint Model Results after Imputation (base Bystanders)

\begin{tabular}{|c|c|c|}
\hline Group & Variables & Coefficients (Std. err.) \\
\hline & Left-Right Ideology $\left(\beta_{1}\right)$ & $0.039(0.190)$ \\
\hline & Auth.-Dem. Ideology $\left(\beta_{2}\right)$ & $0.293^{* * *}(0.079)$ \\
\hline \multicolumn{3}{|c|}{ Potential Protesters } \\
\hline & Valence $\left(\lambda_{\text {Protesters }}\right)$ & $-2.445(1.723)$ \\
\hline & Competence & $-0.724^{* * *}(0.160)$ \\
\hline & Age & $-0.044^{* * *}(0.007)$ \\
\hline & Education & $0.015(0.025)$ \\
\hline & Female & $-0.588^{* * *}(0.154)$ \\
\hline & Log Income & $0.362^{* *}(0.157)$ \\
\hline \multicolumn{3}{|l|}{ Undecideds } \\
\hline & Valence $\left(\lambda_{\text {Undecideds }}\right)$ & $1.860 *(1.071)$ \\
\hline & Competence & $-0.038(0.094)$ \\
\hline & Age & $-0.029^{* * *}(0.003)$ \\
\hline & Education & $-0.046^{* * *}(0.013)$ \\
\hline & Female & $-0.167^{* *}(0.080)$ \\
\hline & Log Income & $-0.049(0.096)$ \\
\hline \multicolumn{3}{|l|}{ CCP Members } \\
\hline & Valence $\left(\lambda_{C C P}\right)$ & $-9.742^{* * *}(1.166)$ \\
\hline & Competence & $-0.075(0.119)$ \\
\hline & Age & $0.048^{* * *}(0.005)$ \\
\hline & Education & $0.214^{* * *}(0.021)$ \\
\hline & Female & $-0.591^{* * *}(0.119)$ \\
\hline & Log Income & $0.368^{* * *}(0.092)$ \\
\hline Observations & 3494 & \\
\hline Log Likelihood & -3620.30 & \\
\hline Note: & ${ }^{*} \mathrm{p}<0.1 ;{ }^{* *} \mathrm{p}<0.05 ;{ }^{* * *} \mathrm{p}<0.0$ & \\
\hline
\end{tabular}


The pre- and post-imputation models also come to the same conclusions when it comes to the issues of competence and valence. Individuals who do not perceive the government to be competent become significantly more likely to say they would consider protesting in the future. Perceptions of government competence do not however determine whether individuals decide to join the Communist party, or explain why some respondents are unsure when asked if they would protest in the future.

Once sociodemographic characteristics and perceptions of competence are taken into account, in both models the CCP Members have a significantly lower exogenous valence $^{6}$ as a group than the Bystanders, or the other groups. This suggests that something other than ideological distance, the perceived competence of the government, or sociodemographic characteristics explains why a relatively small share of the urban population opts to join the Communist party. One possible explanation is that the Communist Party is not seeking to maximize its membership in the same way that parties in democracies seek to maximize votes, since it preferentially admits individuals from the more elite segments of Chinese society.

The model tries to account for this possibility by estimating the effect of sociodemographic valences on political participation. In the imputed sample, respondents are more likely to consider protesting in the future, instead of saying they would never protest, if they are younger, male, and, notably, more affluent, which disconfirms the hypothesis that the poor are the key potential opposition group.

Younger, male, and less educated respondents are more likely to say they are unsure about protesting in the future, again in comparison to the people who would never protest. On the other hand, respondents are more likely to be members of the Communist party if they are older, male, more educated, and come from a higher-income family. The importance of sociodemographic valences for membership in the Communist party is consistent with the argument that in the reform era, the party has strategically recruited elites and intellectuals with less attention to their ideological bona fides.

\footnotetext{
${ }^{6}$ In the joint model, we interpret valence as an intercept which captures the non-ideological reasons to participate once perceived competence and sociodemographic characteristics are taken into account. This encompasses other positive symbols, like honesty or prestige, as well as a host of other factors.
} 
Not all of these relationships are apparent in the pre-imputation sample. While the relationships between age and political participation are the same for all groups, the effects of gender, education, and family income on participation are only significant for Communist party members.

\section{Discussion}

This paper has shown that the spatial model can help explain political participation even when it is applied in a non-democratic context. Chinese citizens are more likely to consider protesting or joining the Communist party if their ideological beliefs are consistent with the preferences of other people engaging in the same types of behavior. However, only the second, Authoritarian-Democratic dimension of ideology produces this effect. Individuals in China do not choose to participate based on the Left-Right dimension, which captures their beliefs about the state's role in the economy.

Valence explains more of the political participation decision than ideology. Individuals are willing to consider protesting if they take a dim view of the government's competence, while sociodemographic characteristics, like education, income, gender, or age explain the decision to become a member of the Communist party.

Of particular interest is the finding that, by the standards of a wide variety of democratic electoral systems, the ideological differences between the Communist party and the members of the potential opposition are relatively small. This suggests that repressing ideological debates among elites and the media can forestall political polarization.

One of the biggest unanswered questions is whether this state of affairs is tenable if the party loses control over political association. A well-known result in the political psychology literature is that members of deliberating groups tend to move towards a more extreme view than the pre-deliberation preferences of those individuals (Sunstein 2002). This suggests that the narrow ideological distances between groups in Chinese society would not survive the onset of open political debate and freedom of association. ${ }^{7}$

\footnotetext{
${ }^{7}$ Though an alternative possibility is that open discussion over political issues reveals differences in opinion within the public, which discourages individuals from engaging in collective action. See Chen and Xu (2017).
} 
If this comes to pass, then political competition in China may turn on ideological differences after all. 


\section{References}

Adams, James F, Samuel Merrill and Bernard Grofman. 2005. A Unified Theory of Party Competition. New York: Cambridge University Press.

Adams, James and Samuel Merrill. 1999. "Modeling Party Strategies and Policy Representation in Multiparty Elections: Why Are Strategies So Extreme?" American Journal of Political Science 43(3):765.

Alvarez, R Michael, Ines Levin and Lucas Núñez. 2017. "The Four Faces of Political Participation in Argentina: Using Latent Class Analysis to Study Political Behavior." The Journal of Politics 79(4):1386-1402.

Ansolabehere, Stephen and James M Snyder. 2000. "Valence Politics and Equilibrium in Spatial Election Models." Public Choice 103(3-4):327-336.

CCP Central Committee. 1981. "On Questions of Party History: Resolution on Certain Questions in the History of Our Party since the Founding of the People's Republic of China." Beijing Review 24(27):10-39.

Chen, Jidong and Yiqing Xu. 2017. "Why Do Authoritarian Regimes Allow Citizens to Voice Opinions Publicly?" The Journal of Politics 79(3):792-803.

Deng, Xiaoping. 1984. Selected Works of Deng Xiaoping, 1975-1982. Beijing: Foreign Languages Press.

Deng, Yanhua and Guobin Yang. 2013. "Pollution and Protest in China: Environmental Mobilization in Context." The China Quarterly 214:321-336.

Dickson, Bruce J. 2014. "Who Wants to Be a Communist? Career Incentives and Mobilized Loyalty in China." The China Quarterly 217:42-68.

Dickson, Bruce J and Maria Rost Rublee. 2000. "Membership Has Its Privileges: The Socioeconomic Characteristics of Communist Party Members in Urban China." Comparative Political Studies 33(1):87-112. 
Downs, Anthony. 1957. An Economic Theory of Democracy. New York: Harper \& Row.

Fu, Diana. 2017. "Disguised Collective Action in China:." Comparative Political Studies $50(4): 499-527$.

Groseclose, Tim. 2001. "A Model of Candidate Location When One Candidate Has a Valence Advantage." American Journal of Political Science 45(4):862.

Guo, Xiaolin. 2001. "Land Expropriation and Rural Conflicts in China." The China Quarterly 166:422-439.

Hotelling, Harold. 1929. "Stability in Competition." The Economic Journal 39:41-57.

Kurella, Anna-Sophie and Franz Urban Pappi. 2015. "Combining ideological and policy distances with valence for a model of party competition in Germany 2009." Journal of Theoretical Politics 27(1):86-107.

Landry, Pierre F and Mingming Shen. 2005. "Reaching migrants in survey research: the use of the global positioning system to reduce coverage bias in China." Political Analysis 13(1):1-22.

Lorentzen, Peter. 2013. "Regularizing Rioting: Permitting Public Protest in an Authoritarian Regime." Quarterly Journal of Political Science 8(2):127-158.

Lorentzen, Peter. 2017. "Designing Contentious Politics in Post-1989 China." Modern China 43(5):459-493.

Lu, Ye, Yajie Chu and Fei Shen. 2016. "Mass media, new technology, and ideology: An analysis of political trends in China." Global Media and China pp. 1-32.

MacFarquhar, Roderick and Michael Schoenhals. 2006. Mao's Last Revolution. Cambridge, MA: Harvard University Press.

Mao, Zedong. 1977. Selected Works of Mao Tse-Tung. Vol. 5 Peking: Foreign Languages Press. 
McKelvey, Richard D and John W Patty. 2006. "A theory of voting in large elections." Games and Economic Behavior 57(1):155-180.

Micozzi, Juan Pablo and Sebastian M Saiegh. 2015. "An empirical stochastic model of Argentina's Impossible Game (1955-1966)." Journal of Theoretical Politics 28(2):266-287.

Nathan, Andrew J and Tianjian Shi. 1996. "Left and Right with Chinese Characteristics: Issues and Alignments in Deng Xiaoping's China." World Politics 48(4):522-550.

O’Brien, Kevin J. 1996. "Rightful Resistance." World Politics 49(1):31-55.

O'Brien, Kevin J and Lianjiang Li. 2006. Rightful Resistance in Rural China. New York: Cambridge University Press.

Oliver, Steven and Kai Ostwald. 2018. "Explaining Elections in Singapore: Dominant Party Resilience and Valence Politics." Journal of East Asian Studies 18(2):129-156.

Pan, Jennifer and Yiqing Xu. 2018. "China's Ideological Spectrum." The Journal of Politics 80(1):254-273.

Plummer, Martyn. 2003. JAGS: A Program for Analysis of Bayesian Graphical Models Using Gibbs Sampling. http://sourceforge.net/projects/mcmc-jags/.

Potter, Pitman B. 2011. "4 June and Charter 08: Approaches to remonstrance." China Information 25(2):121-138.

Quinn, Kevin M. 2004. "Bayesian Factor Analysis for Mixed Ordinal and Continuous Responses." Political Analysis 12(4):338-353.

Riker, William H and Peter C Ordeshook. 1973. An Introduction to Positive Political Theory. Englewood Cliffs, NJ: Prentice-Hall.

Schofield, Norman. 2007. "The Mean Voter Theorem: Necessary and Sufficient Conditions for Convergent Equilibrium." The Review of Economic Studies 74(3):965-980. 
Schofield, Norman and Alexei Zakharov. 2009. "A stochastic model of the 2007 Russian Duma election." Public Choice 142(1-2):177-194.

Schofield, Norman, Claassen, Christopher, Gallego, Maria and Ozdemir, Ugur. 2011. Empirical and Formal Models of the United States Presidential Elections in 2000 and 2004. In Political Economy of Institutions, Democracy and Voting, ed. Norman Schofield and Gonzalo Caballero. New York: Springer pp. 217-258.

Schofield, Norman and Itai Sened. 2005. "Multiparty Competition in Israel, 1988-96." British Journal of Political Science 35(04):635-663.

Schofield, Norman, JeeSeon Jeon, Marina Muskhelishvili, Ugur Ozdemir and Margit Tavits. 2011. Modelling Elections in Post-Communist Regimes: Voter Perceptions, Political Leaders and Activists. In Political Economy of Institutions, Democracy and Voting, ed. Norman Schofield and Gonzalo Caballero. New York: Springer Berlin Heidelberg pp. 259-301.

Schofield, Norman, Maria Gallego and JeeSeon Jeon. 2011. "Leaders, voters and activists in the elections in Great Britain 2005 and 2010." Electoral Studies 30(3):484496.

Schofield, Norman, Maria Gallego, JeeSeon Jeon and Marina Muskhelishvili. 2012. "Modelling Elections in the Caucasus." Journal of Elections, Public Opinion 83 Parties 22(2):187-214.

Schofield, Norman and Micah Levinson. 2008. "Modeling authoritarian regimes." Politics, Philosophy \& Economics 7(3):243-283.

Stokes, Donald E. 1963. "Spatial Models of Party Competition." American Political Science Review 57(02):368-377.

Stokes, Donald E. 1992. Valence Politics. In Electoral Politics, ed. Dennis Kavanagh. Oxford: Clarendon Press pp. 141-164. 
Sunstein, Cass R. 2002. "The Law of Group Polarization." The Journal of Political Philosophy 10(2):175-195.

Wright, Teresa. 2002. "The China Democracy Party and the Politics of Protest in the 1980s-1990s." The China Quarterly 172:906-926.

Wu, Jason and Tianguang Meng. 2016. "The Nature of Ideology in Urban China." Paper Presented at the Annual Meeting of the Midwest Political Science Association, Chicago. 


\section{Supporting Information}

\section{CUGS Survey Measures}

1. Interviewer, please record the sex of the respondent:

1. Male 2. Female

2. In what year were you born?

3. How many years of education have you received?

4. How much was your total family income last year? (Including all pay from work, bonuses, earnings from a second job, gifts from friends and relatives, profits from each kind of investment, other gains, payments in kind, such as grain, cotton, or vegetables, converted to cash, hobby earnings, and wages earned elsewhere, etc.)

5. Are you a Communist Party member?

6. Listed below are a series of political and social activities. Have you ever engaged in any of these activities before?

a) Participated in a political conference

b) Expressed your opinions to leaders at a higher level of government

c) Expressed your opinions through the media

d) Voted in a neighborhood committee election

e) Participated in a protest/demonstration/mass incident

f) Petitioned (either face to face or by mail)

7. Have you frequently, sometimes, occasionally, or never done the following things in response to online political news reports?

a) Participated in online collective action

8. Regardless of whether you have participated in the activities listed, in the future would it be possible for you to engage in these activities?

a) Participate in a protest/demonstration/mass incident 
9. From time to time society faces certain issues, and government must have certain capabilities to deal with these issues. In the issues below, do you think the government's capabilities are very strong, somewhat strong, somewhat weak, or very weak?

a) Capacity to maintain a system of values and education

b) Capacity to maintain social stability

c) Capacity to influence market prices

d) Capacity to monitor tax receipts

e) Capacity to reflect mass opinion

f) Capacity to redistribute goods

g) Capacity to restrain the behavior of officials and government offices 


\section{Original pre-imputation results}

Table A.1: Joint Model Results before Imputation (base Bystanders)

\begin{tabular}{|c|c|c|}
\hline Group & Variables & Coefficients (Std. err.) \\
\hline & Left-Right Ideology $\left(\beta_{1}\right)$ & $0.315(0.367)$ \\
\hline & Auth.-Dem. Ideology $\left(\beta_{2}\right)$ & $0.404^{* * *}(0.150)$ \\
\hline \multicolumn{3}{|c|}{ Potential Protesters } \\
\hline & Valence $\left(\lambda_{\text {Protesters }}\right)$ & $-2.177(2.689)$ \\
\hline & Competence & $-1.132^{* * *}(0.254)$ \\
\hline & Age & $-0.037^{* * *}(0.013)$ \\
\hline & Education & $-0.015(0.049)$ \\
\hline & Female & $-0.381(0.287)$ \\
\hline & Log Income & $0.433^{*}(0.229)$ \\
\hline \multicolumn{3}{|l|}{ Undecideds } \\
\hline & Valence $\left(\lambda_{\text {Undecideds }}\right)$ & $0.755(1.730)$ \\
\hline & Competence & $0.097(0.168)$ \\
\hline & Age & $-0.027^{* * *}(0.008)$ \\
\hline & Education & $-0.048(0.030)$ \\
\hline & Female & $0.121(0.185)$ \\
\hline & Log Income & $-0.046(0.145)$ \\
\hline \multicolumn{3}{|l|}{ CCP Members } \\
\hline & Valence $\left(\lambda_{C C P}\right)$ & $-9.932^{* * *}(2.019)$ \\
\hline & Competence & $0.156(0.207)$ \\
\hline & Age & $0.054^{* * *}(0.009)$ \\
\hline & Education & $0.188^{* * *}(0.036)$ \\
\hline & Female & $-0.542^{* *}(0.219)$ \\
\hline & Log Income & $0.328^{* *}(0.163)$ \\
\hline Observations & \multicolumn{2}{|l|}{831} \\
\hline Log Likelihood & \multicolumn{2}{|l|}{-850.355} \\
\hline Note: & \multicolumn{2}{|l|}{${ }^{*} \mathrm{p}<0.1 ;{ }^{* *} \mathrm{p}<0.05 ;{ }^{* * *} \mathrm{p}<0.01$} \\
\hline
\end{tabular}




\section{Results from Latent Class Analysis}

In the main text of the paper I examined the role that spatial distance and valence played in the decisions to join the Communist party and to consider participating in a protest. Here I present the results of our spatial valence model using an alternative classification scheme for individuals pioneered by Alvarez et al. (2017). Following the method put forward in that paper, I model individuals' propensity to participate by using two binary latent classes. The first of these latent classes captures their tendency to participate in conventional ways, while the second is associated with unconventional behavior. These two classes allow us to divide the survey respondents into four groups: outsiders, who are unlikely to participate in politics in any variety; activists, who are likely participate in both unconventional and conventional ways; agitators, who are likely to participate in unconventional ways but not in conventional ones; and conventionals, who participate in conventional ways but not in unconventional ones.

The state-sanctioned types of conventional participation that I consider in this analysis include attending political conferences, reporting a personal opinion to a higher level of government, reporting a personal opinion to the media, contacting government officials, voting in neighborhood committee elections, petitioning (either face-to-face or by mail), and joining the Communist party. I also consider three types of unconventional participation: participating in online collective action, participating in a protest, and expressing a willingness to protest in the future.

Formally, we have

$$
\begin{aligned}
& Y_{i, j} \sim \operatorname{Bernoulli}\left(p_{i, j}\right) \\
& \operatorname{logit}\left(p_{i, j}\right)=\alpha_{j}+\alpha_{C, j}\left(T_{C, i}-1\right)+\alpha_{U, j}\left(T_{U, i}-1\right),
\end{aligned}
$$

where $Y_{i, j}$ is a binary variable that captures participation in activity $j$ for individual $i$; $p_{i, j}$ is the probability that individual $i$ participates in activity $j$; and $\alpha_{j}$ is an intercept that varies with activity $j . T_{C, i}$ is the conventional trait of individual $i$, which equals 1 if it is low and 2 if it is high; $T_{U, i}$ is the unconventional trait of individual $i$, which equals 1 if it is low and 2 if it is high; $\alpha_{C, j}$ is a nonnegative coefficient that captures 
the influence of $T_{C, i}$ on participation in activity $j$; and $\alpha_{U, j}$ is a nonnegative coefficient that captures the influence of $T_{U, i}$ on activity $j$.

I impose a set of restrictions to ensure identification of the model parameters. I do this by restricting the effect of the conventional trait on participation in protests to be zero $\left(\alpha_{C, \text { protest }}=0\right)$, and by restricting the effect of the unconventional trait on participating in political conferences to be zero $\left(\alpha_{U, \text { conference }}=0\right)$. I also fix the type of the two individuals who participated in all of the conventional activities but none of the unconventional ones to $T_{C, i}=$ High and $T_{U, i}$. $=$ Low. Meanwhile the two individuals who participated in all of the unconventional activities but none of the conventional ones are set to $T_{C, i}=$ Low and $T_{U, i}=$ High.

I used Markov Chain Monte Carlo (MCMC) methods to estimate our models, with the help of the JAGS software package (Plummer 2003). I assigned flat normal priors on $\alpha_{j}$, flat log-normal priors on $\alpha_{C_{j}}$ and $\alpha_{U_{j}}$, categorical priors on the participatory classes $T_{C_{i}}$ and $T_{U_{i}}$, and Dirichlet priors on type probabilities.

Each individual is assigned to one of the four groups on the basis of their type assignments. The scatter plot in Figure A.1 shows the distribution of type assignments for our respondents. I find that $89.7 \%$ of our respondents are assigned a low conventional type ${ }^{8}$, while $93.5 \%$ of individuals are assigned a low unconventional type. The bottom left quadrant of Figure A.1 represents the outsiders, that is, the $83.9 \%$ of the respondents who had a low propensity to participate in both conventional and unconventional ways. The bottom right quadrant contains the conventionals - the $9.6 \%$ of the respondents who were classified as a high type for conventional participation but as a low type for unconventional participation. The activists in the top right represent $0.7 \%$ of the sample and are classified as high type for both conventional and unconventional participation, while the agitators in the top left represent $5.8 \%$ of the respondents; they were classified as possessing a low propensity for conventional participation, but a high propensity for unconventional participation.

\footnotetext{
${ }^{8}$ Individuals are assigned a high type if the model classifies them as a high type more than $50 \%$ of the time; they are assigned a low type if the model classifies them as such at least half the time.
} 


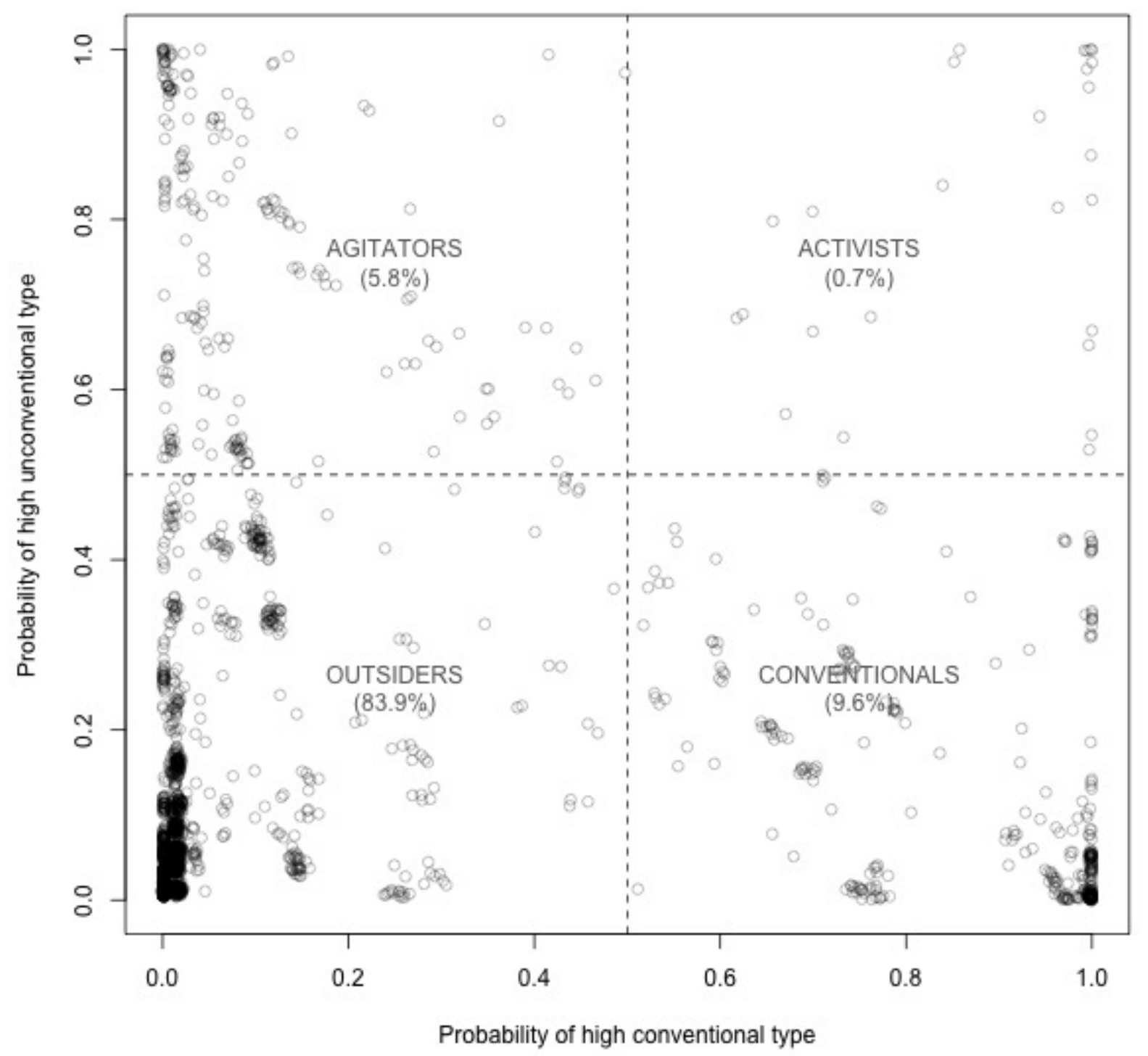

Figure A.1: This plot shows the relationship between the probability of being assigned to a high conventional type (horizontal axis) and the probability of being assigned to a high unconventional type (vertical axis) for respondents of the 2015 Chinese Urban Governance Survey. Each quadrant of the plot represents a latent class of political participation (activists, conventionals, outsiders, and agitators). Circles depict individual respondents. 
Table A.2 presents our estimates and 95\% credible intervals for the parameters $\alpha_{C_{j}}$ and $\alpha_{U_{j}}$, which reflect the effect of a high propensity to participate in conventional or unconventional ways on a given activity $j$. We note that the conventional $\alpha_{C_{j}}$ parameters for attending conferences and joining the Communist party are much larger than the corresponding unconventional $\alpha_{U_{j}}$ parameters. Participating in online collective action, protesting, and expressing a willingness to protest are associated with relatively large unconventional parameters, and relatively small conventional parameters, as we might expect. Meanwhile, both unconventional and conventional latent traits are associated with some types of political participation. Reporting personal views to the media or to higher levels of government, contacting officials, voting, and petitioning load on both participatory types.

Table A.2: Conventional and Unconventional Types of Participation

\begin{tabular}{|c|c|c|c|c|}
\hline & \multicolumn{2}{|r|}{ Conventional $\left(\alpha_{C_{j}}\right)$} & \multicolumn{2}{|c|}{ Unconventional $\left(\alpha_{U_{j}}\right)$} \\
\hline & Mean & 95\% Credible Interval & Mean & 95\% Credible Interval \\
\hline Report to higher level & 5.80 & $(4.95,7.23)$ & 3.12 & $(1.78,4.86)$ \\
\hline Attend conference & 5.42 & $(4.71,6.27)$ & 0.00 & $(0.00,0.00)$ \\
\hline Contact & 2.59 & $(2.27,2.93)$ & 2.77 & $(2.20,3.30)$ \\
\hline CCP membership & 2.44 & $(2.11,2.77)$ & 0.04 & $(0.00,0.39)$ \\
\hline Vote & 2.37 & $(2.08,2.66)$ & 1.55 & $(1.00,2.00)$ \\
\hline Report to the media & 2.06 & $(1.59,2.55)$ & 2.70 & $(2.14,3.27)$ \\
\hline Petition & 1.75 & $(1.13,2.37)$ & 2.68 & $(2.02,3.37)$ \\
\hline Online collective action & 0.05 & $(0.00,0.35)$ & 1.52 & $(0.99,2.20)$ \\
\hline Willingness to protest & 0.03 & $(0.00,0.26)$ & 2.37 & $(1.67,3.33)$ \\
\hline Protest & 0.00 & $(0.00,0.00)$ & 3.58 & $(2.61,4.88)$ \\
\hline
\end{tabular}

Note: The first two columns of this table provide posterior means and $95 \%$ credible intervals for the $\alpha_{C_{j}}$ parameters, which capture the influence of the latent conventional trait on participation in each of the political activities listed. The third and fourth columns provide posterior means and 95\% credible intervals for the $\alpha_{U_{j}}$ parameters, which capture the influence of the latent unconventional trait.

Figure A.2 presents the predicted probability of participating in each of our political activities after conditioning on group membership. The activities are ordered from most to least influenced by the conventional trait (that is, from higher to lower 
values of $\alpha_{C_{j}}$ ). We find that outsiders are relatively unlikely to engage in any variety of political participation. Our model estimates that $18 \%$ of outsiders have turned out to vote at some point, and only $8 \%$ are expected to have contacted government officials; the corresponding figures for all other groups range from roughly $50 \%$ for agitators to in excess of $90 \%$ for activists. The probability of petitioning the government, attending a political conference, or reporting personal views to a higher level of government for outsiders is roughly $1 \%$. Outsiders are also relatively unlikely to engage in unconventional participation. The probability of participating in some kind of online collective action is $16 \%$. $7 \%$ of outsiders are predicted to be willing to consider participating in a protest, and the predicted probability for having already participated in a protest is $0.4 \%$.

Individuals who are categorized as conventionals are roughly as likely as outsiders to participate in unconventional ways. They are however much more likely to vote, attend political conferences, and participate in other state-sanctioned ways. The predicted probability of joining the Communist party for conventionals is $47 \%$, and the figure for reporting personal views to a higher level of government is $65 \%$.

Individuals who are classified as agitators or activists are substantially more likely to have experience with unconventional forms of political participation. The propensity to participate in online collective action or to express willingness to protest is in excess of $40 \%$, while the probability of past protest participation is $12 \%$ for both groups. Both agitators and activists are also more likely to engage in some varieties of confrontational behavior which are nevertheless sanctioned by the state, such as reporting their personal views to the media; the model predicts that $22 \%$ of agitators and $68 \%$ of activists have done so.

Where they differ is in their propensity to participate in conventional ways. Only around $1 \%$ of agitators are predicted to attend political conferences; the analogous figure for activists is $64 \%$. The predicted probability of party membership is $8 \%$ for agitators, but $48 \%$ for individuals who are classified as activists.

Table A.3 presents the proportions and mean ideal points for each group, and Figure 

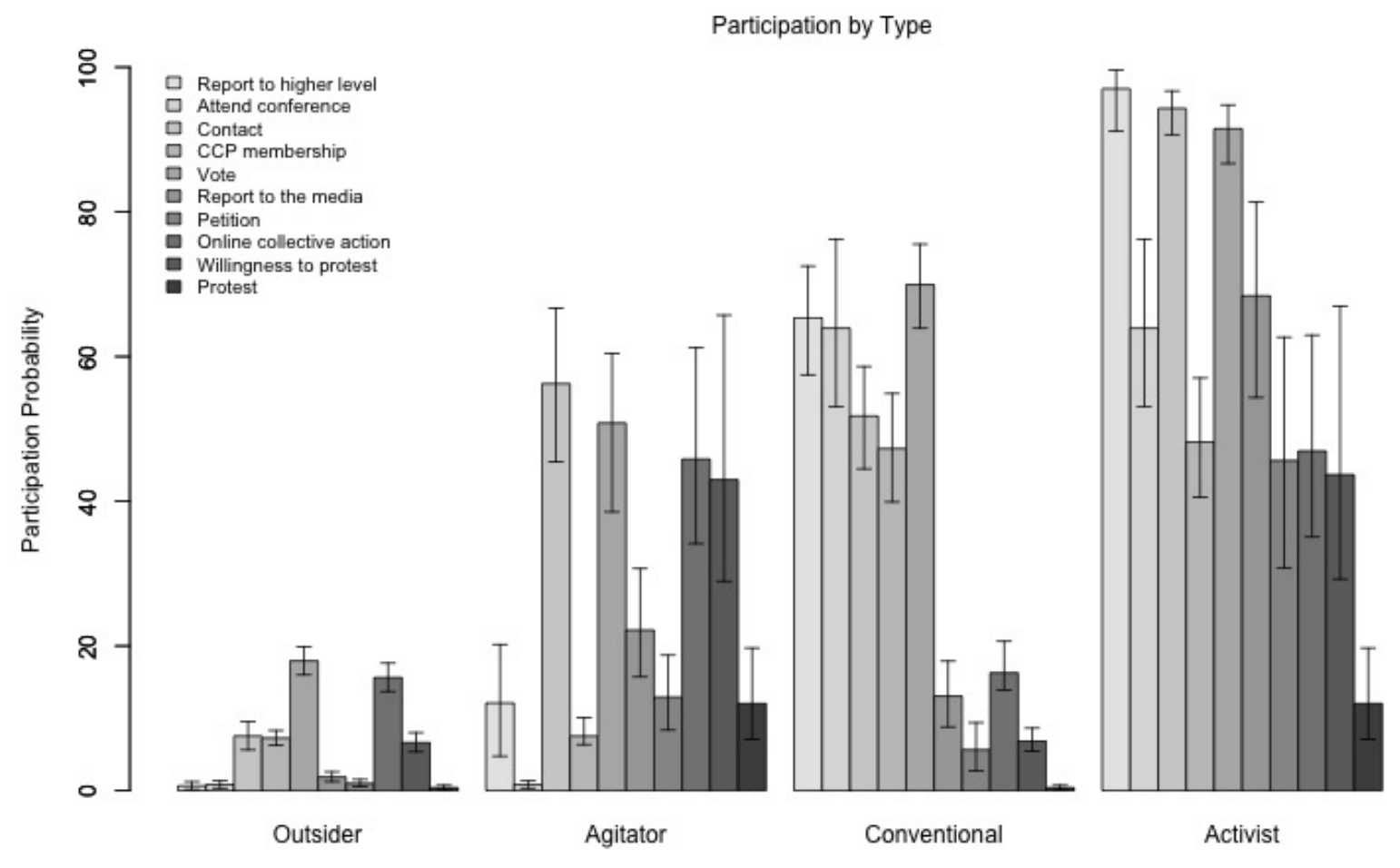

Figure A.2: Participation probabilities by type assignment. This plot depicts the probability of participating in a particular fashion for individuals of a given group assignment (outsiders, agitators, conventionals, and activists). For each group, varieties of political participation are arranged (from left to right) and shaded (from light to dark) from more to less conventional. Bars indicate posterior means and lines represent $95 \%$ credible intervals for the probability of engaging in a given type of participation. 
A.3 presents the overall ideology distribution for our four latent classes. Our results show that the mean ideal points for the four groups are roughly consistent on the first, left-right dimension. The largest difference between groups on this dimension is the distance between conventionals and outsiders: the mean ideal point of the conventionals is roughly a tenth of a standard deviation farther to the left than the outsiders on average.

On the second, authoritarian-democratic dimension, we see some separation between our groups. Outsiders again are close to the average for all respondents, while agitators are about a tenth of a standard deviation more democratic than average. Conventionals are roughly a third of a standard deviation more authoritarian than average. Finally activists are more authoritarian by about half a standard deviation, though since they represent such a small proportion of the sample, their position is more uncertain.

Table A.3: Group Proportions after Latent Class Analysis

\begin{tabular}{lcccc}
\hline \hline Group & Respondents & Percent of Sample & $\begin{array}{c}\text { Mean Left-Right } \\
\text { Ideology }\end{array}$ & $\begin{array}{c}\text { Mean Authoritarian- } \\
\text { Democratic Ideology }\end{array}$ \\
\hline Outsiders & 2947 & $83.9 \%$ & 0.017 & 0.035 \\
Agitators & 203 & $5.8 \%$ & -0.071 & 0.110 \\
Conventionals & 337 & $9.6 \%$ & -0.104 & -0.327 \\
Activists & 26 & $0.7 \%$ & -0.070 & -0.549 \\
\hline
\end{tabular}


Figure A.3: The Ideological Distribution of Latent Classes in China

Ideological Spectrum

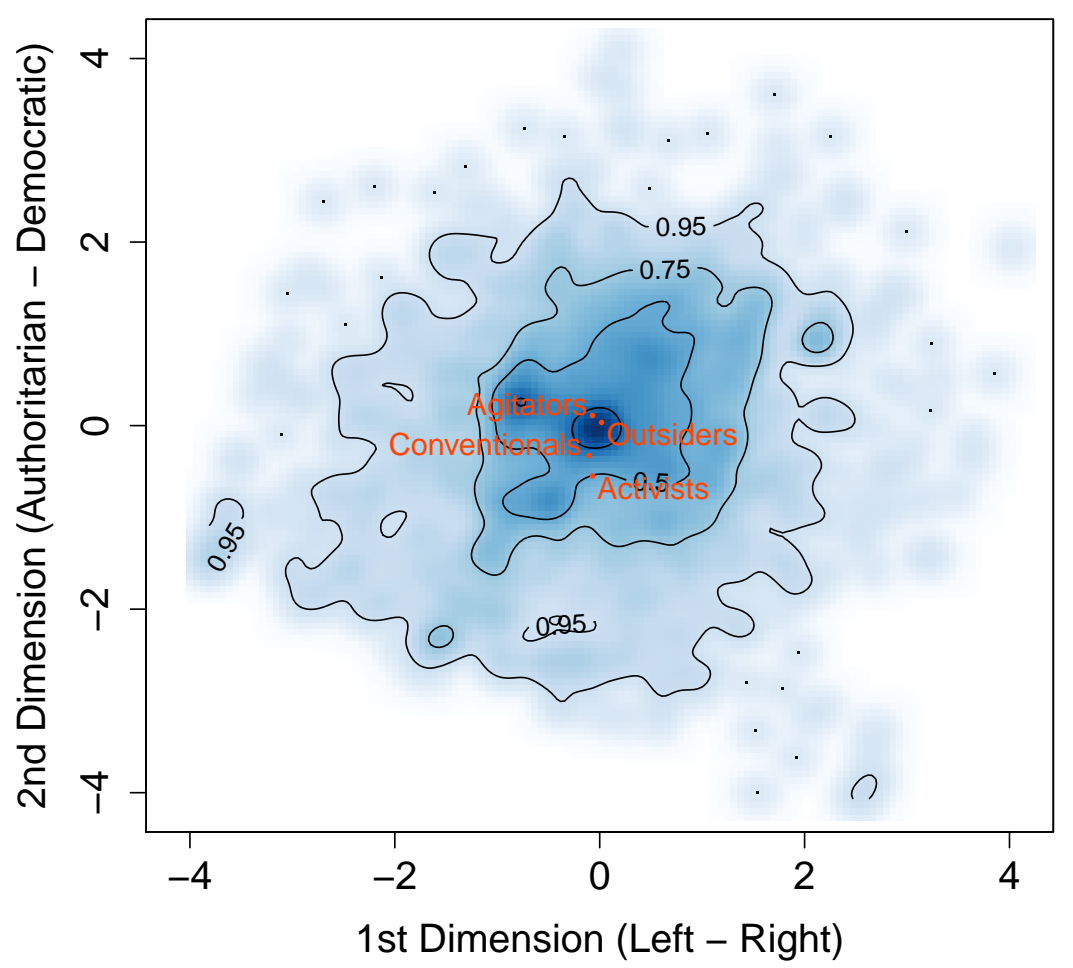

(a) The overall distribution of ideology in the sample

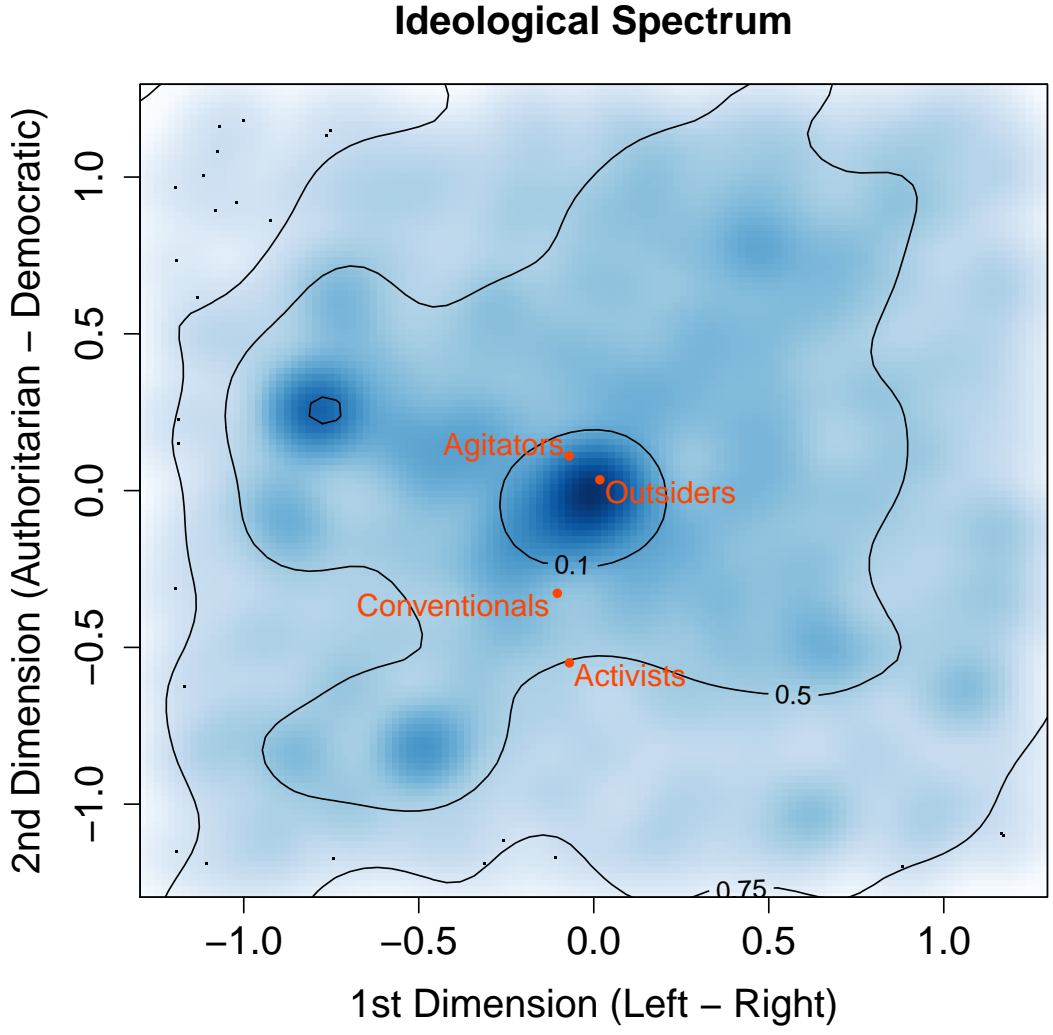

(b) A close-up view of the center of the ideology distribution 
If we estimate our spatial valence model by using outsiders, agitators, conventionals, and activists as our political groups, the findings are similar to the results I presented in the main body of the paper, though several differences do appear. Table A.4 presents the results of the pure spatial model using this classification. ${ }^{9}$ The results from the mixed logit model show that only the spatial coefficient for the second dimension of ideology is significant; spatial distances on left-right economic issues do not appear to factor into political participation decisions.

Table A.4: Pure Spatial Model Results (base Outsiders)

\begin{tabular}{lc}
\hline \hline & Coefficient $($ Std. err. $)$ \\
\hline Left-Right Ideology $\left(\beta_{1}\right)$ & $0.316(0.206)$ \\
Auth.-Dem. Ideology $\left(\beta_{2}\right)$ & $0.467^{* * *}(0.069)$ \\
Valence terms & \\
Agitators $\left(\lambda_{\text {Agitators }}\right)$ & $-2.670^{* * *}(0.073)$ \\
Activists $\left(\lambda_{\text {Activists }}\right)$ & $-4.730^{* * *}(0.198)$ \\
Conventionals $\left(\lambda_{\text {Conventionals }}\right)$ & $-2.170^{* * *}(0.058)$ \\
\hline Observations & 3,513 \\
Log Likelihood & $-1,989.000$ \\
\hline \hline Note: & ${ }^{*} \mathrm{p}<0.1 ;{ }^{* *} \mathrm{p}<0.05 ;{ }^{* * *} \mathrm{p}<0.01$ \\
\hline
\end{tabular}

The findings from the joint model are presented in Table A.5. ${ }^{10}$ Our results from this model suggest once again that ideological distances on the second, authoritariandemocratic dimension play an important role in the political participation decisions of our respondents. The coefficient for spatial distance on the first dimension is also significant in the joint model, but only at the $p<0.1$ level.

The main differences between the joint model estimated here and the one presented in Table 5 have to do with the effect of competence. Whereas in the original results we found that individuals who perceived the government to be less competent were more

\footnotetext{
${ }^{9}$ Once again, valence terms are calculated with respect to the highest valence group, which in this case is the outsiders.

${ }^{10}$ The model was estimated after multiple imputation was used to address missing data concerns.
} 
likely to consider protesting, here the effect of competence is less clear. Perceived government competence in this model does not appear to determine whether individuals are classified as agitators or conventionals, though there is a weakly significant correlation between low perceived government competence and classification as an activist (as opposed to an outsider).

Sociodemographic valences do however play a very similar role as a determinant of group membership. Respondents are more likely to be classified as conventionals (as opposed to outsiders) if they are older, male, more educated, and higher income. ${ }^{11}$ Respondents are more likely to be classified as agitators, rather than outsiders, if they are male and more affluent; they are more likely to fall into the activist category if they are older and better educated. On the whole, the findings from this version of the joint model lend additional credence to our earlier conclusions about the importance of both spatial and valence considerations for political participation in China.

\footnotetext{
${ }^{11}$ The same set of demographic correlations held for CCP Members, as opposed to bystanders, in our initial analysis.
} 
Table A.5: Joint Model Results after Imputation (base Outsiders)

\begin{tabular}{|c|c|c|}
\hline Group & Variables & Coefficients (Std. err.) \\
\hline & Left-Right Ideology $\left(\beta_{1}\right)$ & $0.424^{*}(0.223)$ \\
\hline & Auth.-Dem. Ideology $\left(\beta_{2}\right)$ & $0.349^{* * *}(0.074)$ \\
\hline \multicolumn{3}{|l|}{ Agitators } \\
\hline & Valence $\left(\lambda_{\text {Agitators }}\right)$ & $-6.400^{* * *}(1.334)$ \\
\hline & Competence & $-0.179(0.160)$ \\
\hline & Age & $-0.008(0.006)$ \\
\hline & Education & $0.029(0.023)$ \\
\hline & Female & $-0.800^{* * *}(0.159)$ \\
\hline & Log Income & $0.415^{* * *}(0.110)$ \\
\hline \multicolumn{3}{|l|}{ Activists } \\
\hline & Valence $\left(\lambda_{\text {Activists }}\right)$ & $-8.642^{* *}(3.712)$ \\
\hline & Competence & $-0.741^{*}(0.439)$ \\
\hline & Age & $0.045^{* * *}(0.015)$ \\
\hline & Education & $0.266^{* * *}(0.065)$ \\
\hline & Female & $-0.580(0.419)$ \\
\hline & Log Income & $0.095(0.319)$ \\
\hline \multicolumn{3}{|l|}{ Conventionals } \\
\hline & Valence $\left(\lambda_{\text {Conventionals }}\right)$ & $-11.602^{* * *}(1.482)$ \\
\hline & Competence & $0.026(0.131)$ \\
\hline & Age & $0.064^{* * *}(0.005)$ \\
\hline & Education & $0.200^{* * *}(0.021)$ \\
\hline & Female & $-0.332^{* * *}(0.125)$ \\
\hline & Log Income & $0.389^{* * *}(0.124)$ \\
\hline Observations & 3513 & \\
\hline Log Likelihood & -1803.79 & \\
\hline
\end{tabular}

